\title{
Posterior capsule rupture with herniation of lens fragment following blunt ocular trauma
}

\author{
This article was published in the following Dove Press journal: \\ International Medical Case Reports Journal \\ 30 September 2016 \\ Number of times this article has been viewed
}

\author{
Neeru Choudhary \\ Sameer R Verma \\ Shubhda Sagar \\ Eram Fatima \\ Department of Radiodiagnosis and \\ Imaging, Subharti Medical College, \\ Meerut, Uttar Pradesh, India
}

\begin{abstract}
Posterior capsule rupture with herniated lens fragment in the vitreous cavity on magnetic resonance imaging has not been reported in India until now; however, it has been reported in other countries. Therefore, this study reports the case of a 15 -year-old boy presenting with posttraumatic loss of vision in the right eye due to posterior capsular rupture and herniation of lens material into the vitreous cavity, which was detected by B-scan ultrasonography and magnetic resonance imaging as no ophthalmic examination was possible due to the posttraumatic cataract. The patient was treated by lens aspiration with anterior chamber vitrectomy and placement of posterior chamber intraocular lens, with the patient achieving $6 / 6$ visual acuity postoperatively. This case is unusual due to the rarity of the findings, and it highlights the crucial role of imaging in achieving timely diagnosis and surgery to restore vision in the affected eye.
\end{abstract}

Keywords: posterior capsular rupture, lens fragment herniation, USG, MRI

\section{Introduction}

In blunt nonperforating trauma, lens trauma commonly results in traumatic cataract formation, which leads to failure of any ophthalmoscopy examination. In such cases, preoperative imaging, namely, Scheimpflug imaging, ultrasound biomicroscopy (UBM), B-scan ultrasonography, and magnetic resonance imaging (MRI), can help in the diagnosis and restoring the best possible visual acuity for the patient.

\section{Case history}

The patient's father gave written informed consent to publish this case report. A 15-yearold boy was referred for imaging with blunt trauma to the right eye, which was caused by a cricket ball. He had no history of poor vision before the trauma. Visual acuity in the involved eye at the time of scan was only perception of light. Slit-lamp biomicroscopy or fundoscopy could not be performed due to formation of traumatic cataract. B-scan ultrasonography (Figure 1A, B) revealed normal anterior chamber with distorted echogenic lens with possible herniation of the lens fragment into the vitreous cavity through a breach in the posterior capsule, along with clear posterior chamber. MRI scan (Figure 2) was done for confirmation of ultrasonography (USG) findings, which revealed funneling of hypointense lens material in the vitreous cavity on T2-weighted axial and sagittal images.

Correlating the imaging and clinical findings, a diagnosis of right eye posttraumatic cataract with posterior capsule rupture and herniation of lens fragments into the vitreous cavity through the defect was made. The boy was operated and during
Correspondence: Sameer R Verma Department of Radiodiagnosis and Imaging, Subharti Medical College, $\mathrm{NH}-58$, Meerut, Uttar Pradesh 250005, India

Tel+919756739309

Email drsam74@yahoo.co.in 


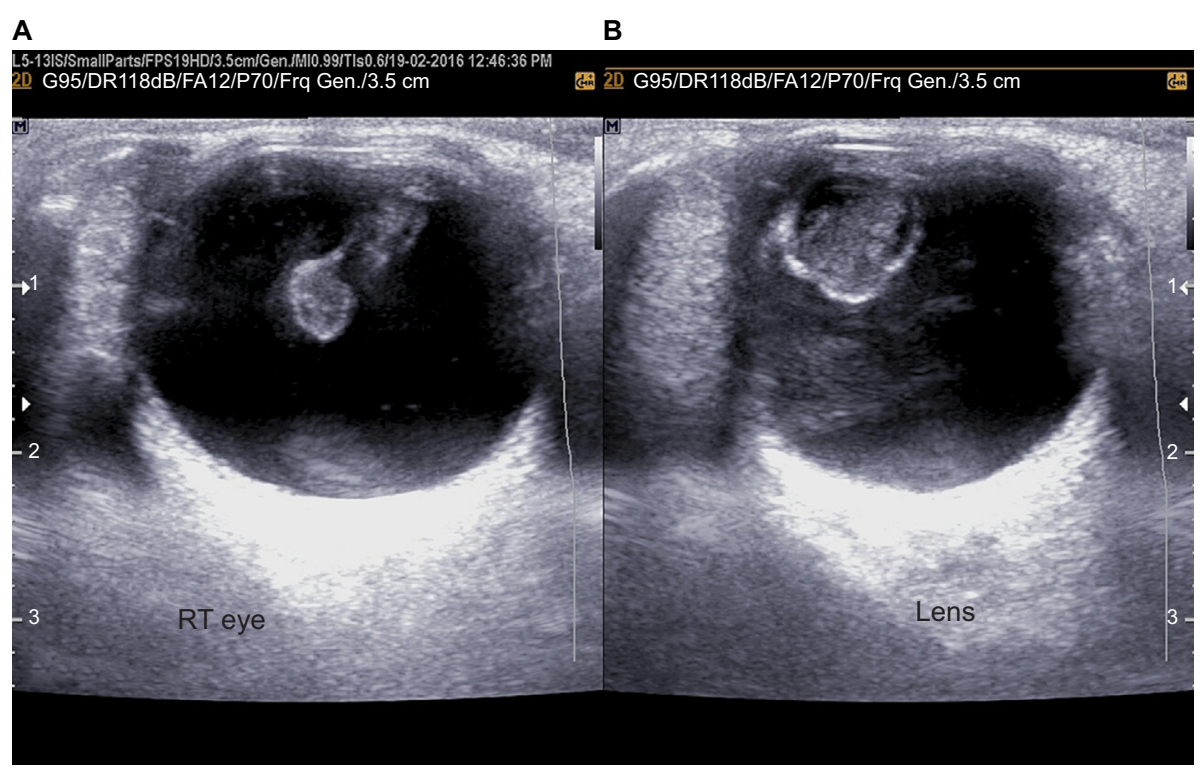

Figure I (A, B) Right eye shows distorted echogenic lens with herniation of lens fragment into the vitreous cavity through a breach in the posterior capsule. Abbreviation: RT, right.
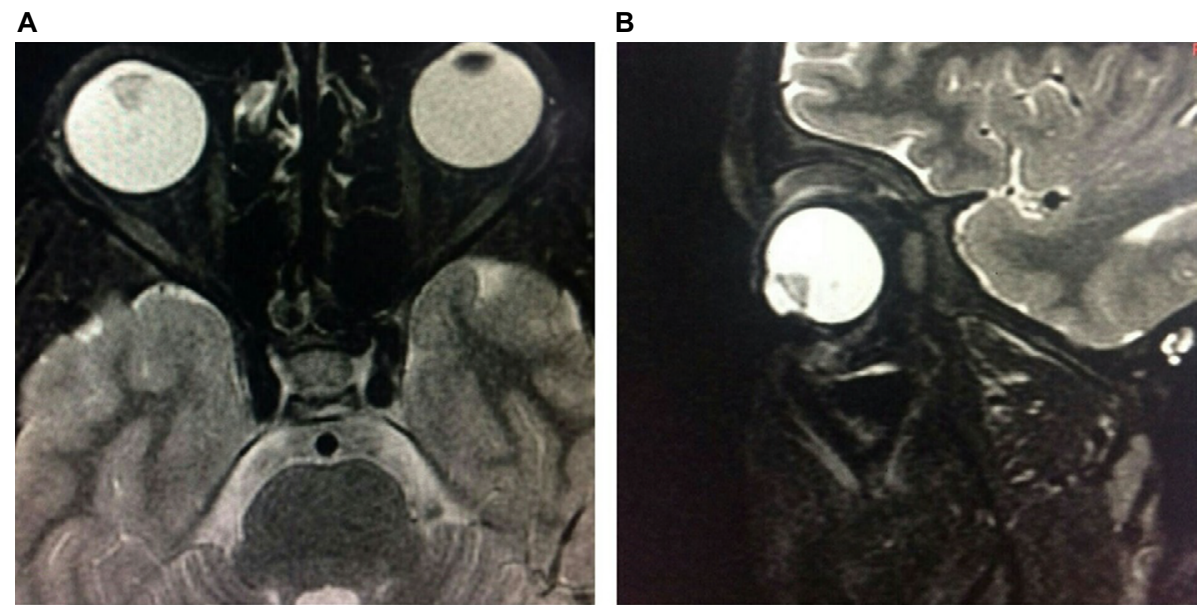

Figure 2 (A, B) T2W axial and sagittal images show hypointense lens material in the vitreous cavity. Abbreviation: $\mathrm{T} 2 \mathrm{~W}, \mathrm{~T} 2$ weighted.

the surgery, anterior vitreous prolapse was found due to preexisting posttraumatic posterior capsular rupture. Hence, an anterior vitrectomy was performed, followed by placement of posterior chamber intraocular lens and a vision of 6/6 was achieved postoperatively.

Preoperative imaging led to a quick diagnosis and early management to save the vision.

\section{Discussion}

Wolter proposed the following hypothesis: first, lens damage can occur due to coup-contrecoup injury, that is, equatorial expansion forces. Second, it is also possible that the absence of a formed nucleus in children and young adults permits the countercoup forces to be transmitted through the lens substance, causing a rupture of thinnest part of the capsule, which is the posterior pole. ${ }^{2}$ Therefore, young age at the time of injury may be an important predisposing factor causing isolated rupture of the lens capsule in patients. ${ }^{3}$ Blum et al described blunt trauma-induced cataracts in 85 patients. More than one-third of these patients had evidence of zonular defects following trauma. ${ }^{4}$ Angra et al reported that hyperplastic epithelial cells migrate and collect on the margins of the posterior capsule break, and undergo fibrous metaplasia in an attempt to heal the defect from 6 to 21 weeks after the lens trauma. ${ }^{5}$

According to Mansour et al, isolated posterior capsule rupture in the event of blunt trauma appears rarely and only 17 cases have been reported until the year $2014 .{ }^{1}$ None of 
these cases were imaged on MRI or had herniation of the lens material into the vitreous cavity.

There are various other methods to detect preoperative posterior capsule rupture. Kucukevcilioglu et al reported preoperative detection of posterior capsule tear with UBM in traumatic cataract, but the disadvantages with UBM are the need for immersion, supine position, and patient cooperation during image acquisition. Also, it is a userdependent technique and requires an experienced imaging technician. Moreover, it is difficult to perform UBM immediately after trauma and in young or uncooperative patients. ${ }^{6}$

Scheimpflug imaging has also been used to demonstrate rupture of the posterior lens capsule after blunt trauma, even with very small defects. Grewal et al reported Scheimpflug imaging of pediatric posterior capsule rupture. ${ }^{7}$ However, images obtained by this method have limited quality in cases with significantly opaque media. Also, the equipment is not available in all the centers. ${ }^{8}$

\section{Conclusion}

This case represents an unusual case of blunt ocular trauma which presented with huge lens material protruding to the vitreous cavity and was diagnosed by MRI. This is the first report about MRI use in such a condition. The posterior capsule rupture with herniation of lens fragment was diagnosed on imaging, leading to early surgical intervention, resulting in a successful visual outcome.

\section{Disclosure}

The authors report no conflicts of interest in this work.

\section{References}

1. Mansour AM, Jaroudi OM, Hamam RN, Maalouf FC. Isolated posterior capsule rupture following blunt head trauma. Clin Ophthalmol. 2014:8:2403-2407.

2. Wolter JR. Coup-contrecoup mechanism of ocular injuries. Am J Ophthalmol. 1963;56:785-796.

3. Rao SK, Parikh S, Padhmanabhan P. Isolated posterior capsule rupture in blunt trauma: pathogenesis and management. Ophthalmic Surg Lasers. 1998;29(4):338-342.

4. Blum M, Tetz MR, Greiner C, Voelcker HE. Treatment of traumatic cataracts. J Cataract Refract Surg. 1996;22(3):342-346.

5. Angra SK, Vajpayee RB, Titiyal JS, Sharma YR, Sandramouli S, Kishore $\mathrm{K}$. Types of posterior capsular breaks and their surgical implication. Ophthalmic Surg. 1991;22(7):388-391.

6. Kucukevcilioglu M, Hurmeric V, Ceylan OM. Preoperative detection of posterior capsule tear with ultrasound biomicroscopy in traumatic cataract. J Catract Refract Surg. 2013;39(2):289-291.

7. Grewal DS, Jain R, Brar GS, Grewal SPS. Scheimpflug imaging of pediatric posterior capsule rupture. Indian J Ophthalmol. 2009;57(3):236-238.

8. Coleman DJ, Silverman RH, Chabi A, Rondeau MJ, Shung KK, Cannata $\mathrm{J}$, Lincoff $\mathrm{H}$. High-resolution ultrasonic imaging of posterior segment. Ophthalmology. 2004;111(7):1344-1351.
International Medical Case Reports Journal

\section{Publish your work in this journal}

The International Medical Case Reports Journal is an international, peer-reviewed open-access journal publishing original case reports from all medical specialties. Previously unpublished medical posters are also accepted relating to any area of clinical or preclinical science. Submissions should not normally exceed 2,000 words or
Submit your manuscript here: https://www.dovepress.com/international-medical-case-reports-journal-journal

4 published pages including figures, diagrams and references. The manuscript management system is completely online and includes a very quick and fair peer-review system, which is all easy to use. Visit $\mathrm{http}: / / \mathrm{www}$. dovepress.com/testimonials.php to read real quotes from published authors. 